\title{
Assessment of the Pollution Load of the Woji Creek Water Body, Port Harcourt, Rivers State, South-South, Nigeria
}

\author{
Iyama $^{1 *}$, William Azuka; Edori ${ }^{2}$, Onisogen Simeon; Nwagbara ${ }^{3}$, Victor Uzoma \\ ${ }^{1}$ Rivers State College of Health Science and Management Technology, Km 6, Oro-Owo, Rumueme, P.M.B.5039, \\ Port Harcourt, Nigeria \\ ${ }^{2}$ Department of Chemistry, Ignatius Ajuru University of Education, Rumuolumeni, PMB 5047, Port Harcourt, \\ Rivers State, Nigeria \\ ${ }^{3}$ Namibia University of Science and Technology, Windhoek, Namibia
}

*Corresponding Author: Iyama, Rivers State College of Health Science and Management Technology, Km 6, Oro-Owo, Rumueme, P.M.B.5039, Port Harcourt, Nigeria

\begin{abstract}
This study was aimed at assessing the pollution load of the Woji Creek River Water in Port Harcourt, Nigeria. This was based on eight water quality parameters of THC, PAHs, TOC, TOM, Oil/ Grease, DO, COD and BOD using three study stations in each area composed of the Woji, Akpajo and Rumuwoji River Water. The DO, BOD, COD were analyzed using Titrimetry, PAHs by the HPLC, TOC by the NDIR, while Oil/ Grease was analyzed by Partition Gravimetry. The result showed highest mean values of $0.68 \pm 0.028$ (THC), $0.27 \pm 0.03$ (PAHs), $5.94 \pm 0.023$ (TOC), 10.24 \pm 0.016 (TOM), $10.78 \pm 0.02$ (Oil/Grease), $5.51 \pm 0.00(D O), 36.40 \pm 0.10(B O D)$ and $104 \pm 1.00$ (COD). The result showed that of partial regeneration but polluted when compared to known permissible limits and previous research studies. This may be attributed to the dilution effect of rainfall. There is an ardent need to monitor and control anthropogenic inputs into this strategically located water body which traverses the oil rich city of Port Harcourt, Nigeria.
\end{abstract}

Keywords: Woji, Akpajo, Rumuwoji, PAHs, Total Organic Matter (TOM), gross organic pollutants

\section{INTRODUCTION}

What quality assessment is the general process of evaluating the physical, chemical and biological nature of a given water body. Some major water quality indicators are Dissolved Oxygen (DO), Biological Oxygen Demand (BOD), Chemical Oxygen Demand (COD) (Iyamaet al., 2017).

Organic pollution and eutrophication indices can be used to quantify the level of water pollution (Liuet al., 2011). Six latent factors could be identified as water quality pollution indices which are; organic, nutrient, physico-chemical, weathering, soil leaching and toxic-anthropogenic (Simeonovetal., 2003).

Research has shown that water quality sources are poorer in rivers than in reservoirs (Wang et al., 2009). Water pollution has become a dynamic challenge and threat to the human race and the environment for some time now (Bu et al., 2009). Determination of the pollution potential of the Woji Creek water using selected physico-chemical parameters is of essence due to the strategic position of this water body. The Woji Creek has experienced a lot of human activities due to the location near an industrial area known as the Trans-Amadi Industrial Layout. According to Anya, Ezekwe and Oyegun(Anya etal., 2017), Sand bag formation and bank erosion around the Cocaine Estate area is a potential threat to urban renewal. Human inputs lead to pollution of the Woji Creek water which poses adverse health risks (Duru et al., 2018). The different sources of water pollution can either be domestic, natural and industrial (Iyama etal., 2017). The levels of pollution of water bodies is quite high and pose greater risk to biodiversity.

An effect of hydrocarbon pollution on the mullet species distribution along the Elechi Creek similar to the study river was relatively higher (Ekweozor, 1989). There are nine water quality parameters which could also be used to determine Water Quality Index of a water body (Iyama and Edori, 2014). 
Result has shown that organic wastes are the major factor responsible for the deterioration of the Woji Creek water (Duru et al., 2018). Alkanes, alkenes and aromatics are the major group of compounds in petroleum hydrocarbons (Adeniji et al., 2017). Total hydrocarbons form one of the common organic contaminants in the marine ecosystem emanating from different sources (RHP, 2004;Oliver, 2008). Similarly, Wu et al (2001), posited that petroleum hydrocarbons found in marine environments come from natural and human controlled sources. Ground water samples are usually contaminated with total petroleum hydrocarbons (Faustorillaet al2017), not to mention surface water. THC is highly toxic to human, animals and other organisms due to their carcinogenicity (Alinoret al., 2014).

Study of water from main outfall drain is impacted by high concentration of total petroleum hydrocarbons (TPH) from natural and anthropogenic sources (Afrahetal., 2014). Polycyclic Aromatic Hydrocarbons (PAHs) are fused aromatic pollutants and are persistent carcinogens in the ecosystem (Mojaetal., 2013). Similarly, PAHs are considered risky xenobiotics (Kabzinskietal., 2002). Results have also shown the relative Pyrolytic dominance of PAHs in water (Kafilzadehetal., 2015).

Oil spills on rivers contribute highly to the increased quantity of PAHs in the ecosystem (Kolleretal., 2004). Chindah et al (2004) added that oil spills on rivers can alter aquatic life. Mastal and Callen (2000) agreed that major source of PAHs emanate from the combustion of fossil fuels, crude oil, coal etc. Hence there is the ardent need to regularly monitor the water bodies around the oil rich Niger Delta of Nigeria to check the levels of PAHs, THC, BOD, DO, COD, Oil and Grease, TOC and TOM. This is because of their toxicity to plants; animals and man as some (e.g PAHs) are very carcinogenic and recalcitrant in the ecosystem (Guinanetal., 2001).

\section{Material AND MethodS}

Water sample were collected at a depth of $20 \mathrm{~cm}$ with pre-cleaned $500 \mathrm{ml}$ laboratory plastic bottles and containers and properly labeled both from upstream and downstream stations. The parameters under study are the gross organic pollutants of DO, COD, BOD; Total Hydrocarbon Content, PAHs, Total Organic Carbon, Total Organic Matter, Oil and Grease. The Florescence Spectroscopy was used to measure the level of hydrocarbon content. Water samples were collected from three major site of Woji / Elelenwo (W), Akpajo / Elelenwo (A) and Rumuwoji/ Elelenwo (R) rivers but centred on three study location labeled as $\mathrm{W}_{\mathrm{A}}, \mathrm{W}_{\mathrm{B}}, \mathrm{W}_{\mathrm{C}} ; \mathrm{A}_{\mathrm{A}} \mathrm{A}_{\mathrm{B}}, \mathrm{A}_{\mathrm{C}}$ and $\mathrm{R}_{\mathrm{A}}, \mathrm{R}_{\mathrm{B}}, \mathrm{R}_{\mathrm{C}}$ respectively.

Dissolve Oxygen $\left(\mathrm{DO}_{1}\right)$ was determine using the Winkler's titrimetry, which was also repeated on same sample after being left for five days in the dark as to obtain another Dissolved Oxygen $\left(\mathrm{DO}_{5}\right)$. The $\mathrm{BOD}_{5}$ was hence determined by the difference between both $\mathrm{DOs}\left(\mathrm{DO}_{1}-\mathrm{DO}_{5}\right)$. Chemical Oxygen Demand (COD), was determined by collecting the water sample in glass bottles and preserved using tetraoxosulphate VI acid $(\mathrm{pH}<2)$ at $4^{\circ} \mathrm{C}$ until analysis in the laboratory using titrimetry and potassium dichromate solution. Sample for the determination of poly-aromatic hydrocarbons was analyzed using high performance liquid chromatography (HPLC) coupled with the fluorescence detection (FLD). Water samples for total organic carbon (TOC) were analyzed using photo-chemical oxidation with UV and a chemical oxidizer, persulphate (Non Dispersive Infra-Red, NDIR).

The amount of Oil and Grease was determined using the partition gravimetric method of the grab sample collected using glass bottles not pre-rinsed with the water before collection since oil and grease are hydrophobic. The sample is preserved with tetraoxosulphate VI acid $(\mathrm{PH}<2)$ and kept cool after collection $\left(\leq 6^{\circ} \mathrm{C}\right)$.

Generally, three samples were collected from each of the major river sources, namely; woji, Akpajo and Rumuwoji. The samples were collected at 2-hours intervals in other to form a representative sample. After all preservation procedures, the samples were transported to the Jaros base laboratory along Iwofe Road, Rumuolumeni, Port Harcourt, Rivers State, Nigeria.

Polycyclic Aromatic hydrocarbons (PAHs) were collected using $250 \mathrm{mls}$ each of the water samples and taken into a separatory funnel, then adjusting the $\mathrm{pH}$ to less than $2(\mathrm{pH}<2)$. The water was extracted twice using $15 \mathrm{mls}$ of methylene chloride. After drying the extract using $5 \mathrm{~g}$ of anhydrous sodium sulphate and concentrating to $1 \mathrm{ml}, 50 \mathrm{mls}$ of $\mathrm{n}$-hexane solvent was then added. This was then extracted to $1 \mathrm{ml}$ again. The concentrate was eluted with $10 \mathrm{ml}$-hexane and fractions collected as 
aliphatic and finally using $15 \mathrm{ml}$ methylene chloride. The resultant extract was then collected as aromatic fraction and concentrated to $1 \mathrm{ml}$ and stored capped in GC vials (Aderinola et.al, 2018).

The study location is on the upper reaches of the Bonny River estuary at latitude $7^{\circ} 1{ }^{\prime} 3^{\prime \prime} \mathrm{N}, 7^{\circ} 1{ }^{\prime} 3^{\prime}$ ' $\mathrm{N}$, and longitude $4^{\circ} 48^{\prime} \mathrm{E}, 4^{\circ} 52 \mathrm{E}$. The creek head water is fresh, flows unidirectional downstream through the Rumuodara swamp. It traverses Port Harcourt Aba express way at the bridge bus stop. The water remains fresh and flows downstream in one direction until it reaches the Mini-Okoro Bridge at Rumuogba where tidal fluxes are observed. The Woji Creek has a confluence with the refinery creek at Okujagu to form the main tributary which drains into the Bonny River. The creek has border with the Port Harcourt Trans-Amadi industrial layout. There are several human settlements and a major abattoir with some thick cover of water hyacinth downstream along the river. The Woji River drainage basin is located at the heart of Obio-Akpor Local Government Areas in Port Harcourt. The Woji River has a meandering flow amid channel blockages upstream as culvert ending creates a fall in the channel. There are sand bag formations along the Cocaine Estate axis and bank erosion posing a threat to urban structures (Anya etal., 2017).

The study involved the Akpajo River axis located at latitude $4^{\circ} 49^{\prime}-4^{\circ} 56^{\prime} \mathrm{N}$ and longitude $7^{\circ} 04^{\prime}-$ $7^{\circ} 05^{\prime} \mathrm{E}$. It is brackish, tidal mudflats and has nipper palm and other macrophytes. This zone serves as a water way to Okrika, Woji and other Port Harcourt suburbs.

\section{RESUlts}

The results of the water quality analysis for the study stations of Rumu woji /Elelenwo, Woj i/Elelenwo, Akpajo/Elelenwo River bodies are shown in Tables 1, 2, 3 and 4. The results are compared to permissible limits and standards as it relates to rivers and drinking water.

The result, showed that the THC ranged from $0.600 \pm 0.028$ to $0.0680 \pm 0.028 \mathrm{mg} / \mathrm{L}$ with a mean of $0.640 \pm 0.04 \mathrm{mg} / \mathrm{L}$ for the Rumuwoji/Elelenwo River; PAHs, $0.24 \pm 0.021-0.30 \pm 0.021 \mathrm{mg} / \mathrm{L}$ with a mean value of $0.27 \pm 0.03 \mathrm{mg} / \mathrm{L}, \mathrm{TOC}, 4.92 \pm 0.042-5.04 \pm 0.03 \mathrm{mg} / \mathrm{L}$ with a mean value of $4.98 \pm 0.06$ $\mathrm{mg} / \mathrm{L}, \mathrm{TOM}, 8.53 \pm 0.042-8.65 \pm 0.042 \mathrm{mg} / \mathrm{L}$ with a mean value of $8.59 \pm 0.06 \mathrm{mg} / \mathrm{L}$, Oil and Grease, $1.00 \pm 0.057-1.16 \pm 0.057 \mathrm{mg} / \mathrm{L}$ with a mean value of $1.08 \pm 0.08 \mathrm{mg} / \mathrm{L}, \mathrm{DO}, 5.35 \pm 0.007-5.38 \pm 0.014$ $\mathrm{mg} / \mathrm{L}$ and a mean value of $5.36 \pm 0.02$, COD, $97 \pm 0.707-99 \pm 0.707 \mathrm{mg} / \mathrm{L}$ and a mean value of $98 \pm$ $1.00 \mathrm{mg} / \mathrm{L}, \mathrm{BOD}, 34.40 \pm 0.141-34.80 \pm 0.141 \mathrm{mg} / \mathrm{L}$ and mean value of $34.60 \pm 0.20$ (Table 1).

Table1. Water Quality Parameters for the Rumuwoji/Elelenwo River

\begin{tabular}{|c|c|c|c|c|}
\hline \multirow{2}{*}{$\begin{array}{l}\text { Parameters } \\
\text { (mg/L) }\end{array}$} & & Stations & & \multirow[t]{2}{*}{ Mean \pm SD } \\
\hline & $\mathbf{R}_{\mathrm{A}}$ & $\mathbf{R}_{\mathrm{B}}$ & $\mathbf{R}_{\mathrm{C}}$ & \\
\hline THC & $0.640 \pm 0.00$ & $0.600 \pm 0.028$ & $0.68 \pm 0.028$ & $0.64 \pm 0.04$ \\
\hline PAHs & $0.27 \pm 0.00$ & $0.30 \pm 0.021$ & $0.24 \pm 0.021$ & $0.27 \pm 0.03$ \\
\hline TOC & $4.98 \pm 0.00$ & $4.92 \pm 0.042$ & $5.04 \pm 0.03$ & $4.98 \pm 0.06$ \\
\hline TOM & $8.59 \pm 0.05$ & $8.53 \pm 0.042$ & $8.65 \pm 0.042$ & $8.59 \pm 0.06$ \\
\hline Oil/Grease & $1.08 \pm 0.00$ & $1.00 \pm 0.057$ & $1.16 \pm 0.057$ & $1.08 \pm 0.08$ \\
\hline DO & $5.38 \pm 0.014$ & $5.36 \pm 0.00$ & $5.35 \pm 0.007$ & $5.36 \pm 0.02$ \\
\hline $\mathrm{COD}$ & $99 \pm 0.707$ & $97 \pm 0.707$ & $98 \pm 0.00$ & $98 \pm 1.00$ \\
\hline BOD & $34.60 \pm 0.00$ & $34.40 \pm 0.141$ & $34.80 \pm 0.141$ & $34.60 \pm 0.20$ \\
\hline
\end{tabular}

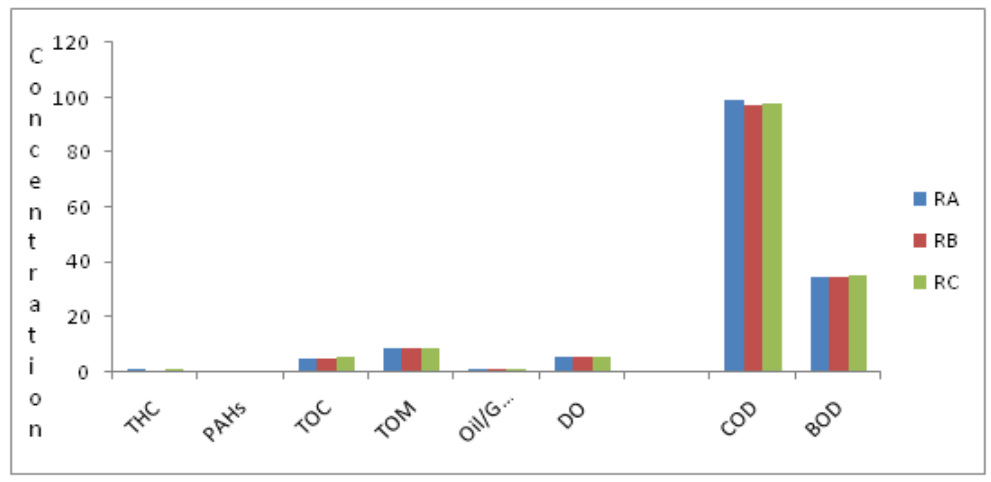

Figure1. Water Quality Variation at Rumuwoji Station 
Assessment of the Pollution Load of the Woji Creek Water Body, Port Harcourt, Rivers State, SouthSouth, Nigeria

Similarly, the results for the Woji/Elelenwo River body recorded ranges for THC as $0.683 \pm 0.001$ $0.687 \pm 0.001 \mathrm{mg} / \mathrm{L}$, and a mean value of $0.685 \pm 0.002 \mathrm{mg} / \mathrm{L}, \mathrm{PAHs}, 0.22 \pm 0.00-0.23 \pm 0.008 \mathrm{mg} / \mathrm{L}$ and a mean value of $0.22 \pm 0.006 \mathrm{mg} / \mathrm{L}, \mathrm{TOC}, 2.93 \pm 0.021-2.99 \pm 0.021 \mathrm{mg} / \mathrm{L}$ and a mean value of $2.96 \pm$ $0.031 \mathrm{mg} / \mathrm{L}, \mathrm{TOM}, 5.12 \pm 0.00 \mathrm{mg} / \mathrm{L}$ and a mean value of $5.12 \pm 0.00 \mathrm{mg} / \mathrm{L}$, Oil and Grease, $10.76 \pm$ $0.014-10.80 \pm 0.014 \mathrm{mg} / \mathrm{L}$ and a mean value of $10.78 \pm 0.02, \mathrm{DO}, 5.34 \pm 0.014-5.39 \pm 0.021 \mathrm{mg} / \mathrm{L}$, and a mean value of $96 \pm 2.00 \mathrm{mg} / \mathrm{L}, \mathrm{COD}, 94 \pm 1.414-98 \pm 1.414 \mathrm{mg} / \mathrm{L}$, BOD, $30.40 \pm 2.263-33.80 \pm 0.141$ $\mathrm{mg} / \mathrm{L}$ with a mean value of $33.60 \pm 1.90$ (Table 2).

Table2. Water Quality Parameters for the Woji Creek

\begin{tabular}{|c|c|c|c|c|}
\hline \multirow{2}{*}{ Parameters (mg/L) } & \multicolumn{3}{|c|}{ Stations } & \multirow{2}{*}{ Mean \pm S.D } \\
\cline { 2 - 4 } & $\mathrm{W}_{\mathrm{A}}$ & $\mathrm{W}_{\mathrm{B}}$ & $\mathrm{W}_{\mathrm{C}}$ & \\
\hline THC & $0.685 \pm 0.00$ & $0.683 \pm 0.001$ & $0.687 \pm 0.001$ & $0.685 \pm 0.002$ \\
\hline PAHs & $0.22 \pm 0.00$ & $0.22 \pm 0.000$ & $0.23 \pm 0.008$ & $0.22 \pm 0.006$ \\
\hline TOC & $2.97 \pm 0.007$ & $2.93 \pm 0.021$ & $2.99 \pm 0.021$ & $2.96 \pm 0.031$ \\
\hline TOM & $5.12 \pm 0.00$ & $5.12 \pm 0.00$ & $5.12 \pm 0.00$ & $5.12 \pm 0.00$ \\
\hline Oil/Grease & $10.78 \pm 0.00$ & $10.80 \pm 0.014$ & $10.76 \pm 0.014$ & $10.78 \pm 0.02$ \\
\hline DO & $5.36 \pm 0.00$ & $5.34 \pm 0.014$ & $5.39 \pm 0.021$ & $5.36 \pm 0.03$ \\
\hline COD & $96 \pm 0.00$ & $98 \pm 1.414$ & $94 \pm 1.414$ & $96 \pm 2.00$ \\
\hline BOD & $33.60 \pm 0.00$ & $30.40 \pm 2.263$ & $33.80 \pm 0.141$ & $33.60 \pm 1.90$ \\
\hline
\end{tabular}

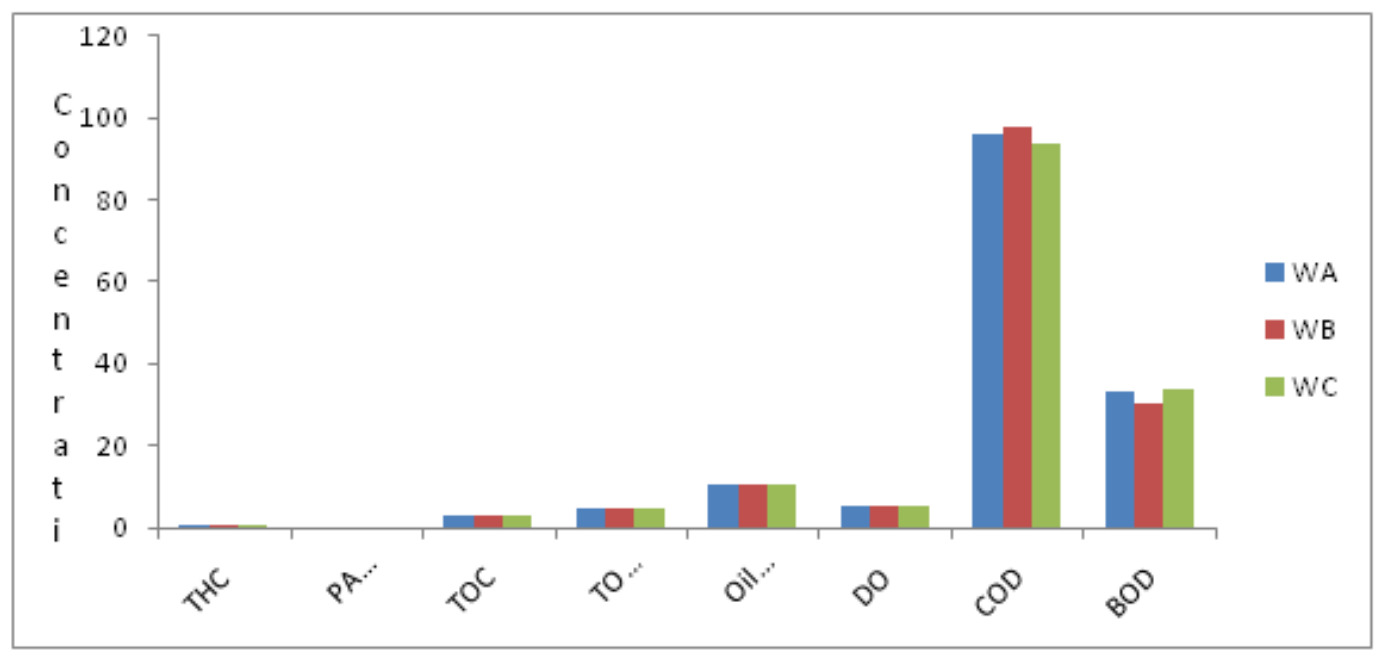

Figure2. Water Quality Variation for the Woji Station

The Akpajo/Elelenwo River has the results in Table 3 as shown. The THC values ranged from $0.733 \pm 0.00-0.735 \pm 0.00 \mathrm{mg} / \mathrm{L}$ and mean value of $0.734 \pm 0.011 \mathrm{mg} / \mathrm{L}, \mathrm{PAHs}, 0.18 \pm 0.007$ $0.20 \pm 0.007 \mathrm{mg} / \mathrm{L}$, with a mean value of $0.19 \pm 0.01 \mathrm{mg} / \mathrm{L}$, TOC, $5.90 \pm 0.028-5.94 \pm 0.00 \mathrm{mg} / \mathrm{L}$, with a mean value of $5.93 \pm 0.02 \mathrm{mg} / \mathrm{L}$, TOM, $10.22 \pm 0.0141-10.26 \pm 0.014 \mathrm{mg} / \mathrm{L}$, with a mean concentration of $10.24 \pm 0.016 \mathrm{mg} / \mathrm{L}$, Oil and Grease ranged from $1.28 \pm 0.007-1.30 \pm 0.007 \mathrm{mg} / \mathrm{L}$ and mean concentration of $1.29 \pm 0.01 \mathrm{mg} / \mathrm{L}, \mathrm{DO}, 5.51 \pm 0.00 \mathrm{mg} / \mathrm{L}$ and a mean value of $5.51 \pm 0.00 \mathrm{mg} / \mathrm{L}, \mathrm{COD}$, $103 \pm 0.707-105 \pm 0.007 \mathrm{mg} / \mathrm{L}$ and a mean concentration of $104 \pm 1.00 \mathrm{mg} / \mathrm{L}$ and BOD, 36.30 $\pm 0.071-$ $36.50 \pm 0.071 \mathrm{mg} / \mathrm{L}$ and mean concentration of $36.40 \pm 0.10 \mathrm{mg} / \mathrm{L}$.

Table3. Water Quality Parameters for the Akpajo/Elelenwo River

\begin{tabular}{|l|l|l|l|l|}
\hline \multirow{2}{*}{ Parameters (mg/L) } & \multicolumn{3}{|l|}{ Stations } & \multirow{2}{*}{ Mean \pm S.D } \\
\cline { 2 - 4 } & $\mathrm{A}_{\mathrm{A}}$ & $\mathrm{A}_{\mathrm{B}}$ & $\mathrm{A}_{\mathrm{C}}$ & \\
\hline THC & $0.734 \pm 0.00$ & $0.735 \pm 0.00$ & $0.733 \pm 0.00$ & $0.734 \pm 0.001$ \\
\hline PAHs & $0.19 \pm 0.00$ & $0.20 \pm 0.007$ & $0.18 \pm 0.007$ & $0.19 \pm 0.01$ \\
\hline TOC & $5.94 \pm 0.00$ & $5.90 \pm 0.028$ & $5.94 \pm 0.00$ & $5.93 \pm 0.02$ \\
\hline TOM & $10.24 \pm 0.03$ & $10.22 \pm 0.014$ & $10.26 \pm 0 .-14$ & $10.24 \pm 0.016$ \\
\hline Oil/Grease & $1.29 \pm 0.00$ & $1.30 \pm 0.007$ & $1.28 \pm 0.007$ & $1.29 \pm 0.01$ \\
\hline DO & $5.51 \pm 0.00$ & $5.51 \pm 0.00$ & $5.51 \pm 0.00$ & $5.51 \pm 0.00$ \\
\hline COD & $103 \pm 0.707$ & $104 \pm 0.00$ & $105 \pm 0.007$ & $104 \pm 1.00$ \\
\hline BOD & $36.50 \pm 0.071$ & $36.40 \pm 0.00$ & $36.30 \pm 0.071$ & $36.40 \pm 0.10$ \\
\hline
\end{tabular}




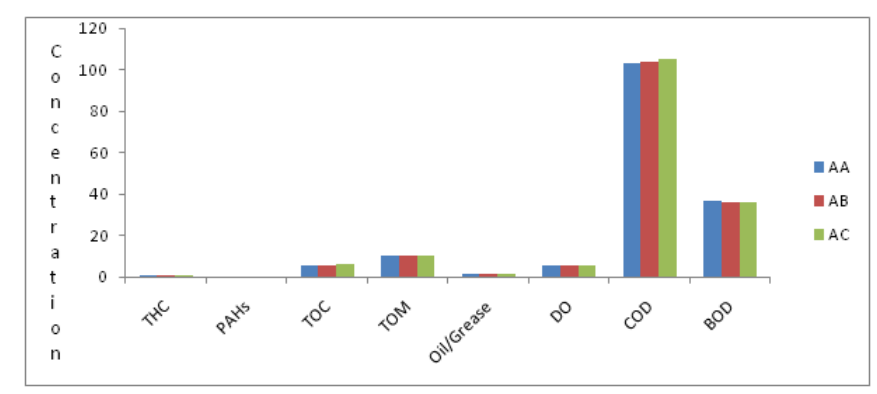

Figure3. Water Quality Variation for the Akpajo Study Station

Table4. Summary of Mean Concentration for the 3-Study Stations

\begin{tabular}{|c|c|c|c|}
\hline \multirow{2}{*}{ Parameters $(\mathrm{mg} / \mathrm{L})$} & \multicolumn{3}{|c|}{ Stations } \\
\cline { 2 - 4 } & $\mathrm{W}$ & $\mathrm{A}$ & $\mathrm{R}$ \\
\hline THC & $0.685 \pm 0.002$ & $0.734 \pm 0.001$ & $0.64 \pm 0.04$ \\
\hline PAHs & $0.22 \pm 0.006$ & $0.19 \pm 0.01$ & $0.27 \pm 0.03$ \\
\hline TOC & $2.96 \pm 0.031$ & $5.94 \pm 0.023$ & $4.98 \pm 0.06$ \\
\hline TOM & $5.12 \pm 0.00$ & $10.24 \pm 0.016$ & $8.59 \pm 0.06$ \\
\hline Oil/Grease & $10.78 \pm 0.020$ & $1.29 \pm 0.01$ & $5.36 \pm 0.020$ \\
\hline DO & $5.36 \pm 0.030$ & $5.51 \pm 0.00$ & $98 \pm 1.00$ \\
\hline COD & $96 \pm 2.00$ & $104 \pm 0.00$ & $34.60 \pm 0.20$ \\
\hline BOD & $33.60 \pm 1.90$ & $36.40 \pm 0.10$ & \\
\hline
\end{tabular}

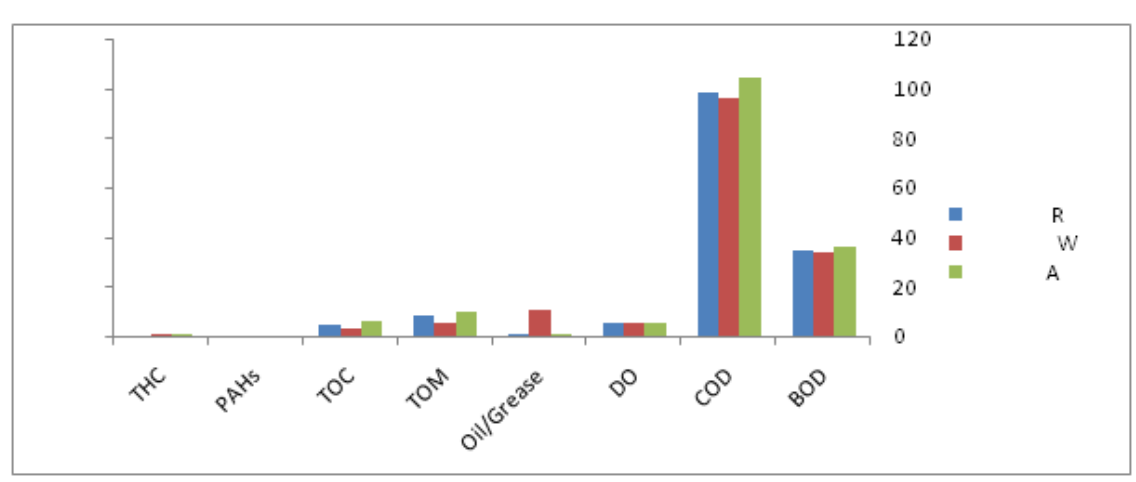

Figure4. Spatial Variation of the Water Quality Parameters (Rumuwoji, Woji, Akpajo)

\section{DISCUSSION}

The result showed that total hydrocarbon content (THC) in $\mathrm{mg} / \mathrm{L}$ recorded a mean value of $0.6400 \pm .04$ where the station $R_{C}$ had the highest value of $0.68 \pm 0.28 \mathrm{mg} / \mathrm{L}$. The THC remain one of the common organic contaminant in the aquatic ecosystem (Oliver, 2008), though the aliphatics and aromatics are the major groups of compounds in petroleum hydrocarbons (Adenijiet al., 2017). This value is far lower than that earlier observed for the same Creek (Onojake et al., 2011). This may mean some self-regeneration and reduction in effluent discharge into the creek. Similarly, higher values were also recorded for the Bonny River ${ }^{26}$. The values so obtained are far below the established permissible level of $10 \mathrm{mg} / \mathrm{L}$ in water (Wokoma, 2015). The THC is the quantity of the measured hydrocarbon impurities and usually expressed in methane equivalent (Wu etal., 2001). Similarly, Inyanget al., (2018) worked on the surface water of Qua-Iboe River, Ibeno, Akwalbom State, Nigeria. Moslen and Miebaka (2017), also recorded relatively high values in a study of the Azuabie Creek. Though Afrah et al (2014), recorded similar low values in southern Iraq outfall drain. This indicates low contamination of THC in the water body for the Woji Creek. The Akpajo axis recorded the highest concentration. The polycyclic Aromatic hydrocarbons (PAHs) are considered to be the fused aromatic pollutants which show persistence carcinogenic effects on man (Mojaetal., 2013). For PAHs, the Rumuwoji axis recorded the highest mean value of $0.27 \pm 0.35 .94 \pm 0.00 \mathrm{mg} / \mathrm{L}$, but lower than those recorded by Chen et al., (2018) in River Basin water in Poland. Though the values were lower than those obtained in River Ethiope, Asaba-Ase and Egbokodo in Nigeria, there is still a threat of PAHS to aquatic life within the examined waterbody. This is also similar to the insignificant variation of PAHs across the study stations for the Badagry Creek and were also within WHO recommended 
limits (Guinan et al., 2001). Koller et al (2004) observed that human activities contribute enormously to the increased quantity of PAHs in the ecosystem. Oil Spills on rivers and combustion of fossil fuels can increase the potentials of PAHs and alter aquatic life (Mastal and Callen, 2000; Chindah etal., 2004). The variation of the water quality for the stations is shown in Figures 1, 2, 3, and 4 respectively.

Total Organic Carbon (TOC) recoded the mean value of $4.98 \pm 0.06 \mathrm{mg} / \mathrm{L}$ atthe Rumuwoji Station, $2.96 \pm 0.0315 .94 \pm 0.00 \mathrm{mg} / \mathrm{L}$ at Woji and $5.94 \pm 0.23 \mathrm{mg} / \mathrm{L}$ at Akpajo Study locations. The Akpajo/Elelenwo location had the highest concentration of TOC, which was similar to those of Azuabie Creek when compared to the Okujagu Creek (Moslen and Miebaka, 2017), though below the $500 \mu \mathrm{g} / \mathrm{g}$ regulated by DPR. They also posited that sediments from the study area of the Azubie Creek fall within moderate high pollution of TOC and hence toxic to aquatic life. The \% TOC for Mat Rivers varied from $0.216 \%$ to 1.416 at the most polluted sites (Lazel etal, 2011). Relatively, TOC values are lower than Dissolved Oxygen (DO) values (Schmacher, 2012). The values though below permissible limits require monitoring to prevent further depletion of the water body.

Total Organic Matter (TOM) recorded its highest concentration at the Akpajo Study Station. This may be attributed to the location of the study station being an exit point, hence accumulation of organic matter and high human activities around the area. The highest concentration of $10.24 \pm 0.016 \mathrm{mg} / \mathrm{L}$ was recorded at the Akpajo station whereas the least value of $5.12 \pm 0.00 \mathrm{mg} / \mathrm{L}$ was observed at the Woji/Elelenwo River axis. The Woji axis is more monitored due to its exposure level to the authorities, unlike the Akpajo and Rumuwoji axis of the Creek. Lower mean value of $0.048 \pm 0.017$ $\mathrm{mg} / \mathrm{L}$ was recorded by Davis and Tawari (2010), which were lower than those obtained, although within the permissible limit of range 1-30 $\mathrm{ml} / \mathrm{l}$ for natural waters.

The presence of Oil and Grease in the Woji Study Station of mean value $10.78 \pm 0.02 \mathrm{mg} / \mathrm{L}$ compared to the lower values of $1.29 \pm 0.01 \mathrm{mg} / \mathrm{L}$ at Akpajo and $1.08 \pm 0.08 \mathrm{mg} / \mathrm{L}$ at Rumuwoji is not unconnected with the industrial and certain oil activities around the area. Organic wastes are the major factors responsible for the depletion of the water quality as reported by Duruetal., (2018) on the Woji Creek water.

Dissolved Oxygen (DO) measured in $\mathrm{mg} / \mathrm{L}$ recorded the highest mean values of $5.51 \pm 0.00 \mathrm{mg} / \mathrm{L}$ whereas the Woji and Rumuwoji Study Stations had the same mean values of 5.36 \pm 0.03 and 5.36 \pm $0.02 \mathrm{mg} / \mathrm{L}$ respectively. Similarly, Lazel et al.(2011) observed higher values of DO within the range of $9.55-9.77 \mathrm{mg} / \mathrm{L}$. Woke and Monday (2017) observed relatively higher mean values of $10.33 \mathrm{mg} / \mathrm{L}$. The value range of $1.6-10.1 \mathrm{mg} / \mathrm{L}$ was recorded by Hart and Zabbey(2005) in same Woji River, which was not far from those of this study. This showed that DO is reducing which is an indication of pollution as aquatic organisms may suffocate due to reduced DO and decay of organic matter.

The values of DO recorded for the Trans-Okpoka Creek ranged between 0.0-5.6mg/L, which also corroborates the result of this study $(5.34-5.51 \mathrm{mg} / \mathrm{L}$ ) within the Woji River (Davis and Tawari, 2010). Onojake and Emereole(2011) recorded similar mean values, though below those of the study $(2.4 \pm 0.3 \mathrm{mg} / \mathrm{l})$. The values so observed were higher than the reference values indicating pollution potentials. The recommended minimal value for domestic use and fish population maintenance is $5 \mathrm{mg} / \mathrm{L}$ (Duru etal., 2017). Water with low DO of $2-5 \mathrm{mg} / \mathrm{L}$ is hypoxic but less than $0.5 \mathrm{mg} / \mathrm{l}$ is anoxic whereas reports show that DO levels less than $3 \mathrm{mg} / \mathrm{L}$ are stressful to most marine organisms.

The mean value observed for biological oxygen demand (BOD) was $33.60 \pm 1.9 \mathrm{mg} / \mathrm{L}$ (Woji), $36.40 \pm 0.10 \mathrm{mg} / \mathrm{L}$ (Akpajo/Elelenwo) and $34.60 \pm 0.20 \mathrm{mg} / \mathrm{L}$ (Rumuwoji). These values are higher than the reference values indicating pollution as similar values of range $0.20-98 \mathrm{ml}$ was recorded earlier (Hart andZabbey,2005). Emekaetal., (2009), recorded slight acidity due to the high BOD values in both seasons. Davis and Tawari, (2010) observed similar values, though slightly higher mean values and attributed it to temperature and putrefaction of substance deposited in the studied creek from human activities. Woke and Monday (2017) in their study of the Akpajo River recorded a range of $1.2-4.3 \mathrm{mg} / \mathrm{L}$ and extremely lower than those of the study station. This relatively higher BOD can be attributed to the prevailing pollution index of the creek. 
Chemical Oxygen Demand (COD, in $\mathrm{mg} / \mathrm{L})$ recorded the following ranges Woji $(94-98 \mathrm{mg} / \mathrm{L}$ ), Akpajo (103-104 mg/L), Rumuwoji (97-99 mg/L), but with mean values of $96 \pm 2.00,104 \pm 1.00$ and $98 \pm 1.00 \mathrm{mg} / \mathrm{L}$ respectively. Onojake and Emereole (2011) reported higher value range of $131.4-$ $132: 7 \pm 0.9 \mathrm{mg} / \mathrm{L}$ but Duru et al. (2018) recorded a range of $16.0-530 \mathrm{mg} / \mathrm{L}$ and a mean of $127.33 \pm 7.91$ $\mathrm{mg} / \mathrm{L}$. The COD increases downstream of the Woji Creek which is similar to the observations in the study stations.

\section{CONCLUSION}

The concentrations of organics showed that there is moderate pollution especially the THC and PAHs. The presence of oil/ grease and the total organic matter is also an indication of the River water depletion. Though DO level fell within the minimum permissible limit, serious check and control be taken to avoid future decrease as this is still not acceptable for cold water but for warm water hence still a threat to sustainable aquatic life. The values obtained for COD and BOD indicated pollution though lower than most cases earlier reported. The result results showed those of a regenerating water body probably due to some control measures against indiscriminate anthropogenic inputs and the flooding cases of fresh water bodies.

\section{REFERENCES}

[1] Adeniji, A. O., Okoh, O. O. \&Okoh, A. I. (2017). Analytical Methods for the Determination of the Distribution of Total Petroleum Hydrocarbons in the Water and Sediments of Aquatic Systems: A Review. Journal of Chemistry, Vol.2017, ID 5178937, 13pp, https://doi.org/10.1155/2017/5178937

[2] Aderinola, O. J., Mekuleye, G. O. \&Whenu, O. O. (2018). Total and Polyaromatic Hydrocarbons in Water, Sediment, Fin and Shellfishes from Badagry Creek and Ologe Lagoon, Lagos, Nigeria. Journal of Applied Science and Environmental Management, 22 (5): 675-680.

[3] Afrah, A. M., Basim, Y. A. \&Zahraa, Z. A. (2014). Evaluation of Total Hydrocarbon Levels and Trace Metals in Water and Sediment from Main Outfall Drain in Al-Nassiriya City/ Southern Iraq. Natural Resources, 5, 795-803.

[4] Alinor, I. J., Ogukwe, C. E. \&Nwagbo, N. C. (2014). Characteristic Level of Total Petroleum Hydrocarbon in Soil and Groundwater of Oil Impacted Area in the Niger Delta Region, Nigeria. Journal of Environmental Earth Science, 4 (23), 188-194.

[5] Anya, M. U. K., Ezekwe, C. I. \&Oyegun, C. U. (2017). Morphological analysis of the Woji River in Port Harcourt, Nigeria; using temporal data and Mathematical algorithm. Landform Analysis, 35:45-54

[6] Bu, H., Tan, X., Li, S. \& Zhang, Q. (2009). Temporal and Spatial Variations of Water Quality in the Jinshui River of the South Qinling Mts., China. Ecotoxicology and Environmental Safety, 73(5): 907-913

[7] Chen, Y., Sun, C., Zhang, J. \& Zhang, F. (2018). Assessing 16 Polycyclic Aromatic Hydrocarbons (PAHs) in River Basin Water and Sediments Regarding Spatial-Temporal Distribution, Partitioning and Ecological Risks. Polish Journal of Environmental Studies, 27(2):579-589.

[8] Chindah, A. C., Braide, S. A. \&Sibeudu, O. C. (2004). Distribution of Hydrocarbons and Heavy Metals in Sediments and a Crustacean (Shrimps Penaeusnotialis) from the Bonny / Calabar River Estuary, Niger Delta; AJEAM-RAGEE, 9: 1-17.

[9] Davis, O. A. \& Tawari, C. C. (2010). Seasonal and tidal effects on sediment characteristics of TransOkpoka Creek; Upper Bonny Estuary, Nigeria. Agriculture and Biology Journal of North America, 92-93.

[10] Duru, C. C., Daniel, U. I. \&Ogbulie, J. N. (2018). Impacts of Organic Wastes on Water Quality of Woji Creek, Port Harcourt, Nigeria. Journal of Applied Sciences and Environmental Management, 22 (5):625-630.

[11] Ekweozor, I. K. E. (1989). A review of the effect of oil pollution in West African Environment. DiscoveryandInnovation, 1(3): 27-37

[12] Emeka, U. J., Braide, S. A. \& Chindah, A. C. (2009). Impact of abattoir wastes based on some physicochemical parameters on Woji Creek, Port Harcourt, Nigeria. Management of Environmental Quality, 20(5): 581-591.

[13] Faustorilla, M. V., Chen, Z., Dharmarajan, R. \& Naidu, R. (2017). Determination of Total Petroleum Hydrocarbons in Australian Groundwater through the Improvised Gas Chromatography Flame Ionization Detection Technique. Journal of Chromatographic Science, 55(8): 775-783.

[14] Guinan, J., Charlesworth, M., Service, M. \& Oliver, T. (2001). Sources and Geochemical Constraints of Polycyclic Hydrocarbons in Sediments and Mussels of two Northern Irish Sea Loughs. Marine Pollution Bulletin, 42 (11): 1073-1081.

[15] Hart, A. I. \&Zabbey, N. (2005). Physico-Chemistry and Benthic Fauna of Woji Creek in the Lower Niger Delta, Nigeria. Environment\& Ecology, 27(2):361-368. 
[16] Inyang, S.E., Aliyu, A.B. \&Oyewale, A. O. (2018). Total Petroleum Hydrocarbon Content in Surface Water and Sediment of Qua-Iboe River, Ibeno, Akwa-Ibom State, Nigeria. Journal of Applied Sciences and Environmental Management, 22(12):1953-1959.

[17] Iyama, W. A. \&Edori, O. S. (2014). Seasonal Variation in Water Quality during Dredging of Brackish Water Habitat in the Niger Delta, Nigeria. Trends in Applied Sciences Research, 9(3):153-159.

[18] Iyama, W. A., Eugene-Nwala, O. \&Igoni, I. K. (2017). Assessment of the variations in physicochemical parameters and heavy metals pollution potentials of Ekerikana waterbody, Rivers State, Nigeria. International Journal of Chemistry, Pharmacy and Technology, 2(4): 162-168

[19] Kabzinski, A. K. M., Cyran, J. \&Juszczak, R. (2002). Determination of Polycyclic Aromatic Hydrocarbons in Water (including drinking water) of Lodz. Polish Journal of Environmental Studies, 11(6): 695-706.

[20] Kafilzadeh, F. (2015). Distribution and Sources of Polycyclic aromatic hydrocarbons in Water and Sediments of the Soltan Abad River, Iran. The Egyptian Journal of Aquatic Research, 41 (3): 227-231.

[21] Koller, K., Brown, T., Spurgeon, A. \& Levy, L. (2004). Recent Development in Low Level Exposure and Intellectual Impairment in Children. Environmental Health Perspective, 112 (9): 987-994.

[22] Lazel, A., Lazo, P. \&Arapi, V. (2011). Determination of Total Organic Carbon (TOC) in Sediment of Mat River. Journal of International Environmental Application \& Science, 6 (5):699-703.

[23] Liu, S., Lou, S., Kuang, C., Huang, W., Chen, W., Zhang, J. \&Zhong, G. (2011). Water quality assessment by pollution-index method in the Coastal waters of Hebei Province in Western Bohai Sea, China. Marine Pollution Bulletin, 62(10): 2220-2229

[24] Mastal, A. M. \& Callen, M. S. (2000). A Review on Polycyclic Aromatic Hydrocarbon (PAHs) Emissions from Energy Generation. Environ-mental Science and Technology, 34(15): 3051-3057.

[25] Moja, S. J., Mtunzi, F. \&Madlanga, X. (2013). Determination of Polycyclic Aromatic Hydrocarbons (PAHs) in River Water Samples from the Vaal Triangle Area in South Africa. Journal of Environmental Science, Health, Toxic and Hazardous Substances and Environmental Engineering, 48(8): 847-54.

[26] Moslen, M.\&Miebaka, C. A. (2017). Hydrocarbon Contamination of Sediment in the Niger Delta Region: a case study of the Azubie Creek, Upper reaches of the Bonny Estuary, Nigeria. IOSR Journal of Environmental Science, Toxicology and Food Technology, 11(9):26-32.

[27] Oliver, C. (2008). Report on Issues Relating to the Potential Relocation of the Port Elizabeth Manganese Terminal and Tank Farm to the Port of Nggura, Port Elizabeth Regional Chamber of Commerce, Port Elizabeth, South Africa.

[28] Onojake, M. C. \&Emereole, N. E. (2011). Analytical Studies on Pollution Index of River Woji in Port Harcourt, Nigeria. Research Journal of Soil and Water Management, 2(1): 1-5.

[29] RHP (2004). River Health Programme, State- of- Rivers Reports: Buffalo River System, Department of Water Affairs and Forestry, Pretoria, South Africa.

[30] Schmacher, B. A. (2012). Methods for the Determination of Total Organic Carbon (TOC) in Soils and Sediments. United States Environmental Protection Agency, Environmental Sciences Division National Exposure Research Laboratory, Las Vegas.

[31] Simeonov, V., Stratis, J. A., Samara, C., Zachariadis, G., Voutsa, D., Anthemidis, A., Sofoniou, M. \&Kouimtzis, T. (2003). Water Research, 37 (17):4119-4124

[32] Wang, Y., Tang, K., Xu, Z., Tang, Y.S., Liu, H. (2009). Water quality assessment of surface drinking water sources in cities and towns of China. Department of Water Resources; China Institute of Water Resources and Hydropower Research, Beijing, China.

[33] Woke, G. N. \& Monday, N. (2017). Physico-chemical Parameters and Heavy Metal Content of Akpajo River, Rivers State. International Journal of Research in Agriculture and Forestry, 4 (12):20-23.

[34] Wokoma, O. A. F. (2015). Levels of Total Hydrocarbons in Water and Sediment of a Polluted Tidal Creek, Bonny River, Niger Delta, Nigeria. International Journal of Scientific and Technology Research, 3(12):351-354.

[35] Wu, Y., Zhang, J., Mi, T. Z. \& Li, B. (2001). Occurrence of n-alkanes and polycyclic aromatic hydrocarbons in the core sediments of the Yellow Sea. Marine Chemistry, 76 (1-2):1-15

Citation: Iyama, "Assessment of the Pollution Load of the Woji Creek Water Body, Port Harcourt, Rivers State, South-South, Nigeria”, International Journal of Advanced Research in Chemical Science, vol. 7, no.1 , p. 1-8, 2020. DOI: http://dx.doi.org/10.20431/2349-0403.0701001

Copyright: () 2020 Authors. This is an open-access article distributed under the terms of the Creative Commons Attribution License, which permits unrestricted use, distribution, and reproduction in any medium, provided the original author and source are credited. 